\title{
Healing Bereavement through Rituals: A Review of the WeppaWanno Widowhood Purification Practices
}

\author{
Michael Onyedika Nwalutu \\ University of Toronto, Toronto, Canada \\ Email: nwalutu@yahoo.co.uk
}

Received January $15^{\text {th }}, 2012$; revised February 22 ${ }^{\text {nd }}, 2012$; accepted April $4^{\text {th }}, 2012$

\begin{abstract}
This paper explores the traditional widowhood rites in Mid Western Nigeria's WeppaWannoland, as a spiritual and psychosocial process of purification and healing for loss induced trauma. The choice of WeppaWannoland in this investigation stems from this people's peculiar and extensive purification ritual which is designed to heal the bereaved in three-dimensions-spirit, soul and body. The investigation focuses on the differential impact of bereavement practices on WeppaWanno widows, for there are two distinct marriage statuses prevalent in the society, and to set the scene for comparing the merits of indigenous rites with Western bereavement practice and resulting respective experience. This work incorporates indigenous health and healing along with psychoanalytical approaches in making sense of the bereavement rituals. In this investigation, I shall be drawing largely from a pool of data from ethnographic field work carried out between 2001 and 2004 in WeppaWannoland, and other related materials.
\end{abstract}

Keywords: Healing; Widowhood; Trauma

\section{Introduction-Background of Study}

\section{WeppaWannoland}

The WeppaWannoland is located on the western side of the river Niger, across from the Igala kingdom. It is flanked in the west by Avianwhu, in the south by Ekperi, both Etsako clans, and in the north by Ibirraland. It is located between Latitude $6^{\circ} \mathrm{E}-7^{\circ} \mathrm{E}$ and Longitude $6^{\circ} \mathrm{N}-7^{\circ} \mathrm{N}^{\cdot}$ The Niger itself runs from the north to the south along the eastern border of the land. The vegetation of the area varies from secondary rain forest in the south and along the bank of the Niger, to tropical grassland and savannah. The population of WeppaWanno is sparse. It was estimated to be about 43.2 persons to a square mile in 19361937, and between 150 to 350 persons to a square mile in the 1970s. By 1991 when Etsako East Local Government (county council) was created, comprising seven clans namely; Avianwhu, Ekperi, Okpekpe, Okpella, South Uneme, Three Ibies, and Weppa Wanno; the population was approximately 143,903 people, with Agenegbode as administrative headquarters and Okpella and Fugar exhibiting the features of semi-urban towns. Aspects of the people's cultural heritage that have been iretrievably dislodged by two major imperialist incursions that redefined the political, and therefore, the economic and sociocultural history of WeppaWannoland, are the Amoya and Adegbe constructs of female categories. The Islamic jihadist invasion and slave raids of the Nupe Kingdom that took place in the first half of the nineteenth century followed by the Western colonial conquest and Christian missionary incursions in early twentieth century, eroded the customary foundations upon which the powers exercised by women in these categories were rooted. The imbalance in power dynamics entrenched by colonialism served to reinforce Western-type patriarchy in the society, influencing how marriage, and therefore widowhood and bereavement practices were enacted. In the cultural blending following these invasions, noticeable distortions were made to existing cultural practices (Bello-Imam, 1995: p. 97; Harunah, 2003: p. 379; Nwalutu, 2004: p. 42). The Adegbe and Amoya female statuses became the center of interest in this work considering the shift of WeppaWannoland from a balance between matriarchy and patriarchy as evidence in some pre-colonial African societies to the Western type patriarchal chiefdom. In seeking to understand the implications of imperialism in complex repositioning of female gender and widowhood practices in WeppaWanno, I realized that although much has been written about gender formation, categorization and manifestation in Africa (e.g Ogundipe-Leslie, 1994; Cornwall, 2005; Arnfred, 2004; Ngunjiri, 2010), a little has been done to help in understanding the influence of the double-tragedies of Nupe/Islamic invasions and Western/Christian incursion on the repositioning of feminity and the depletion of power inherent in female status as reflected in the contemporary Adegbe and Amoya statuses in WeppaWannoland. In addition, not much is documented that could expose how these external socio-political forces have worked to reconstruct and reshape feminine gender categories and power relations which in turn dictate how widowhood rituals have been adapted and rationalized in WeppaWanno society. The superimposition of Islamic and Christian norms, values and mores on WeppaWanno tradition as a result of colonization supplanted the original male-female power balance, leaving in its wake a type of Arabic-Western pseudo-patriarchy and a community embroiled in socio-political chaos.

\section{Why WeppaWannoland? Why Me? Statement of Problem}

The geographical position of WeppaWanno locates it in the centre of Nigerian socio-cultural activities. Situated in the middle of Edo state, Nigeria, the community is bordered across the Niger River by Idah, the capitol city of the Igala kingdom; Igbo 
nation in the East, and Yoruba nation in the West. WeppaWannoland represents a cultural confluence of these various regions of the country, resulting diverse Nigerian cultural heritages finding their niche in its cultural blend. As an Igbo indigene from Eastern Nigeria, I arrived in WeppaWannoland, Edo State (province), of Mid-Western Nigeria in 2001 (with my research colleague and two indigenous interpreters) on an ethnographic research trip aimed at exploring history and culture in order to situate the biographical work on Pa Isibor Michael Aken'Ova (MON). It was during one of the interviews that were an essential part of this research that we encountered the stunning dimension of pre-colonial gender and power relations embodied in the Amoya and Adegbe institutions peculiar to WeppaWanno that are fast waning, leaving a trail of social ills, communal conflicts, and court cases. Most of our female interviewees were widowed Adegbe village group heads who would interject their responses by relating what situations used to be, and would have been, in cases of Amoya widows, thus drawing our attention not only to changes enforced by the colonial rulers, but the existing divide in power relations of gender, not just between male and female binary opposites, but within "female" as a gender category. Comparable institutions are not known either in Eastern Nigeria where I hail from or in any other geopolitical zone of the country.

The Igbo peoples east of the Niger practiced a widowhood ritual that was distinct from what obtained in other regions. The tradition was eliminated almost completely by the combination of colonial encounter and the introduction of Christian faith. Most of the other cultural communities in southern Nigeria faced acculturation permeated by both Islamic and Christian values resulting from imperialist expansions in early histories of their societies. For although the indigenous peoples inhabiting the larger part of what presently is known as the NorthWest geo-political zone (including such states as: Jigawa, Kaduna, Kano, Katsina, Kebbi, Sokoto and Zamfara experienced Islamic conversion and Arabic imperialism and domination dating back to $11^{\text {th }}$ century A.D. (Isichei, 1983: p. 143); societies in the North-East geo-political zone, including: Adamawa, Bauchi, Borno, Gombe, Taraba and Yobe were later to be influenced by the Islamic religion and Arabic culture via the extension of Jihadist movements later in the century (see: Fafunwa, 1974). The influence of Islamic faith and culture on the societies within the North-Central-Benue, Kogi, Kwara, Nasarawa, Niger, Plateau-and areas in the present Federal Capital Territory, Abuja trickled down (to a degree) through various jihadist movements and the social dynamics of inter-tribal relations. The peoples in the South-East (including: Abia, Anambra, Ebonyi, Enugu, and Imo states); South-South (Akwa Ibom, Bayelsa, Cross River, Delta, Edo and Rivers states); and SouthWest (Ekiti, Lagos, Ogun, Ondo, Osun and Oyo states) geopolitical zones were almost not influenced by Islamic movement, hence were largely converted into Christian faith in the era of colonization. I deemed it expedient to investigate the widowhood rituals as an aspect of WeppaWanno healing and health traditions, not only to contribute to the burgeoning literature in African cosmology, health and healing but because of the community's peculiar marriage and widowhood features (Bello-Imam, 1995; Harunah, 2003; Nwalutu, 2004) that could be found in no other population in the six geo-political zones of Nigeria. Okeke-Ihejirika (2004) and Opara (2000) acquiesce in the truism that marriage and motherhood are priority issues in a traditional African female's aspiration, yet Achebe (2005),
Isichei (1983), Aderinto (2001), Fasoranti and Aruna (2007) upheld Mba (2005) and Mbiti (1975) that the pains and grief emanating from widowhood practices in contemporary African societies might dampen the joy of motherhood especially when indigenous comprehensive processes of recovery are neglected. At this juncture, certain obvious questions begin to emerge: Is the current trend in widowhood practices in WeppaWannoland sequel to the cultural collision and encapsulation informed by Nupe invasion and Western colonization? Does it symbolize a shift from the pre-colonial traditions resulting from the blend of indigenous practices with Islamic and Christian traditions? Is it yet a reinvention of an insidious pre-colonial ritual that got disrupted by Islamic and Christian traditions? Whatever the response to these questions, I imagined that turned between the imposed Arabic (Islamic) and Western (Christian) domestic ideologies which tend to obscure the established indigenous widowhood rituals, and normalize African women's subordinate status as housewives (McIntosh, 2009; Ogundipe-Leslie, 1994; Ngunjiri, 2010), the colonizers have subverted the traditional practices of extensive grief and mourning (designed to facilitate full recovery of the bereaved from the distress of spousal loss); and this might be responsible for the current visible disjunction and dissonance in the prevailing spiritual and social atmosphere in WeppaWannoland.

It is my view that an understanding of the intersections of the foreign dominant praxes within the indigenous ritual space is critical to an evaluation and appreciation of the consequences of inadequate time for grieving in the contemporary WeppaWanno society with its attendant negative psychosocial outcomes. For when an indigenous way of life (that sustains and enhances harmony and balance with the human environment) is either disrupted or ignored what results is "disease" or disorders (Pesek, Helton, \& Nair, 2006; Johnston, 2002; Colomeda \& Wenzel, 2000), that are generally preventable using the indigenous world views on health and healing, and for which colonialist biomedicine has not proven to be a panacea. Using textual analysis in making sense of the vast literature and data on widowhood in and around pre-colonial and post-colonial WeppaWanno African society, I will continue to interrogate the problems inherent in the extirpation of the WeppaWanno widowhood rituals and their subsequent domination by the brief, inclement Islamic and Christian practices with the following questions: How might we begin to understand the pre-colonial WeppaWanno widowhood rituals as a healing and recovery tool? What impact did the Nupe invasion and Western colonization have on the status of WeppaWanno women? How have the Islamic and Christian bereavement practices influenced widowhood practice in WeppaWanno today? In what ways are the indigenous WeppaWanno widowhood rituals more beneficial to the spiritual and psychosocial recovery of the bereaved than the present foreign traditions? In this investigation I will engage the lenses of indigenous health and healing, and psychoanalytical approaches in making sense of traditional WeppaWanno widowhood rituals as a way of evaluating the health relevance of the pre-colonial bereavement rituals in WeppaWannoland. I will draw largely from a pool of data collected during ethnographic field work carried out between 2001 and 2004 in WeppaWannoland by Felicia Nwalutu and the author in the company of two local interpreters, Cletus Izobo and Martin Itseme. I will also be using data from existing and relevant literature on indigenous bereavement practices in Africa and elsewhere. 


\section{Theoretical Framework}

This work incorporates indigenous world views on health and healing and psychoanalytical approaches in making sense of the pre-colonial bereavement rituals in WeppaWannoland. Common to the themes in the literature on indigenous peoples' notions of health and healing is a broad definition that goes beyond physical wellness to include the tripartite balance of spirit, soul and body in alignment with human environment (Colomeda, 1999; Konadu, 2007; Balick, 2006; Linklater, 2010; Turner, 2006). In indigenous health and healing perspective, abnormal health conditions are neither rigidly and narrowly defined as physiological infections by pathogens nor as disorders of the psychological systems as in biomedicine. Rather, abnormal health conditions could be a result of intrapersonal or interpersonal dislodgement from the rhythms of life. It might as well result from disruptions in, or a disconnect from, the natural environment. Whatever the source of the dissonance, there is an imbalance in the circle of life to which the individual patient belongs. Healing, wellness, and recovery must therefore follow the path of reconciling the individual with other parts of the circle through relevant therapies and rituals. The widowhood bereavement trauma is a good example of both interpersonal and intrapersonal disruption, and according to WeppaWanno tradition, recovery from the shock of bereavement was met with a diviner's prescription for a series of rituals, lasting up to one year in the indigenous calendar, designed to heal the widow's spirit, soul, and body.

The forceful colonization of indigenous peoples put the West in a position of power from which its representatives arrogantly devalorized the health practices of the natives as superstition (Balick, 2006; Linklater, 2010; Turner, 2006). Until recently Western medical practitioners have debunked the potency and efficacy of rituals and herbal treatment in alleviating human distresses. However critical analysis of literature on both biomedicine and ethnomedicine continues to find parallels between indigenous and western health practices. Rasmussen (2007), for instance, undermines the claim of Western medicine as secular, a claim that created a barrier to understanding the value of ethnomedical practices that included rituals and spirituality along with ethno-pharmacology. By revealing biomedicine as not being "entirely secular", Rasmussen's work broke the barrier between sacred and secular, myth and science which advocates of biomedicine have used to negate the potency of ethnomedical practices so that investigations into indigenous worldviews on illness, health and healing systems would not be assessed using the standards of biomedical practices, rather through the lenses of cultural competence. At the moment, areas of divergence and convergence are clear between ethnomedicine and biomedicine, but the two may be seen as complementary. In her special lecture at OISE, University of Toronto, Chinese medical expert, Dr Yan Ki (May, 2011) summed up the complementary roles of Western and Chinese indigenous medicine. According to her, biomedicine is effective in curative or therapeutic healing while ethnomedicine is excellent in protracted cures and prophylactic applications. This puts paid to the judgmental argument that categorizes Western medicine as superior and indigenous medicine as inferior or "alternative". For according to Johnston (2002) alternative must not be assumed to mean inferior or traditional, but representing options people have for treatment. According to Johnston, what constitutes significant difference between biomedicine and the tradi- tional ideas of health, illness, and healing is the latter's inseparability from religion and concern with spiritual issues (p. 198). The use of rituals in healing especially by the spiritual healers and diviners includes the recognition that sickness or ailment may result not just from bacteria, virus infection or malfunction of the psychological or neurological systems, but from a disconnect between the individual(s) concerned and the circle constituting the holistic reference of life (including relationships with the spiritual and physical environments) or from the dislocation caused by traumatic experiences like loss or deprivation.

Unlike biomedicine that pathologizes situations that could not easily be explained by science, ethnomedicine uses its modes of enquiries to ascertain the point and dimension of disconnect and allows ritualized or therapeutic remedies as required. For instance, biomedical practice prescribes nerve sedating drugs for a patient suffering from trauma-induced depression, often worsening the situation, in contrast with ethnomedical practice of indigenous groups in North America who would recommend enquiries and resolution the healing circle and use of a sweat lodge to arrive at spiritual and mental catharsis (Turner, 2006: p. 121). This pattern of healing also applies to the widowhood rituals in the pre-colonial WeppaWanno society. It is easy hence to see why the biomedical approach to mental health or psycho-social problems still leaves so much to be desired.

The World Health Organization's (WHO) description of health includes physical, mental, social, and spiritual wellbeing. Colomeda and Wenzel (2000) insist on the other hand, that the meaning of health and its application in everyday life should be determined by the culture and worldviews of the people concerned, not imposed on them by a dominant culture (p. 244), raising the question of what happens when a people's cultural, and therefore, healthcare system is violently disrupted? Linklater (2010) depicts colonization and its medical tool as a forceful suppression of indigenous people's ways of life. Similarly, Fanon (1991) recounts the ambivalent attitude with which indigenous peoples relate to the colonizer's "modes of presence". The domination is not only perpetuated through capturing and using the means of production and distribution of knowledge, but also using medicine as a tool to access a people's life-ways.

However indigenous peoples' understanding of human health as comprising the physiological, spiritual and intellectual in (constant relationship with) the terrestrial, celestial and transcendental (spiritual powers) is only beginning to make sense to science-obsessed Western medical practitioners whose attempt to perpetuate the colonial project using medical maneuvers is increasingly frustrated by positive results achieved by indigenous health practices in specific contexts. Many health issues that could not be resolved by biomedicine have been resolved by indigenous healing procedures. Only in this light shall we begin to imagine and estimate the enormity of the disruptions implied in the displacement of the WeppaWanno people's bereavement rituals with the culturally counter-productive Arabic and European practices.

\section{Trauma in Bereavement: Indigenous Healing from Psychoanalytical Lens}

This paper further examines the WeppaWanno widowhood 
rituals through the lens of psychoanalytical thoughts on trauma. Trauma is an emotional or psychological shock that may produce disordered feelings or behavior (Davis, 2001). Expatiating on the effects of trauma, Franz Fanon sees the psychological roots of Black people's trauma in the Diaspora as a product of slavery, colonialism and deep seated racism that have had lasting effects on the psyches of families and communities (Hayes, 1996 in Gayle, 2010: p. 108). Of relevance to WeppaWanno widowhood rituals here, is the understanding that psychological trauma has lasting psychosocial implication for the individual(s) concerned. It is Fanon's view that trauma and psychosis are not merely a consequence of wars between the colonizers and the colonized, but rather, are symptoms attributable to racism, brutality, and protracted attacks on daily experiences of the colonized peoples, the effects of which are repressed in the subconscious minds of the victims (p. 110). However, Fanon addresses group or collective psychological trauma with reference to the impact of Western colonization and slavery on the psyche of Black peoples in the Diaspora, while this work is focused on the healing effects of widowhood rituals on the personal psyche of individual widow(s) in their native context. Sigmund Freud's psycho-analytical model expounded in his work "mourning and melancholia” might also be useful here.

I have to emphasize at the onset that the use of a Western analytical framework represented by Freud to buttress my emphasis in the indigenous health and healing approaches is not intended to be confrontational, but it is rather a deliberate move to elicit similarities in views and possible departures. For example, both Freud and indigenous health approaches recommend prolonged, rigorous and complete bereavement and mourning exercise as a way of purging the psyche of the bereaved of the trauma of loss and its paralyzing effects. Sigmund Freud, Erich Lindermann and Colin M. Parkes agree with the indigenous tradition of widowhood bereavement in which sufficient time is allowed the bereaved to navigate around the huge barrier of emotional impairment and receive a renewed self image and the mental stability to engage in a new relationship (in Kahn, 2002: p. 178). In fact, Parkes berates both Europe and North America for their apparent lack of rituals of bereavement and institutional opportunities in these societies which he claims result in enormous negative socioeconomic consequences (p. 178). I will argue however that although Freud, his contemporaries and other psychoanalysts appeared to have corroborated indigenous approaches on grieving and mourning, they seem neither to understand nor agree with the ritualistic aspect of the grieving exercise. For in the WeppaWanno widowhood traditions the focus is not simply on the mental or psychological recovery from trauma, but on the holistic cure of the bereaved person-spirit, soul and body. It is at this point that Western scientific view on health digresses from the indigenous worldviews. Moreover, the indigenous rituals of bereavement ensure a healthy spiritual environment within which the widow is reestablished in a new relationship with members of her community, while the psychoanalytical view is concerned primarily with the individual psyche as is manifest in the bereaved's disposition and behavior.

According to Freud, we invest a great deal of psychic energy (libido) on people we deem very important to us and our relationship with them. This energy is also invested in all important memories and associations linked to such relationships and the more important the relationship, the greater the energy invested. If the person invested with such energy dies, the energy be- comes homeless, producing acute grief in the bereaved person (in Kahn, 2002: p. 172). The enormity of grief accompanying this situation is tantamount to the importance of the relationship that was lost. Freud argues that it is through a protracted, painful and laborious grieving that the bereaved engage in retrieving the psychic energy invested in each memory associated with the deceased and that the trauma diminishes with the progress of the mourning. At the end all the invested energy will be retrieved for investment in a new relationship. Freud's argument here is consistent with the experiences shared by bereaved WeppaWanno women who have gone through the indigenous widowhood rituals and is similar to the response Dr Njoki Wane received interviewing a group of African refugees in Israel. According to Wane, she was interviewing a group of elders from African community in Israel to ascertain their view on the persistent cases of anti-social behavior, psychotic dispositions, depression and related psycho-social disorders in their community. This team of knowledgeable elders disclosed to her that they needed sufficient time to grieve for their loved ones who died in the desert while they were in transit to Israel (Wane, 2011). According to them, the activities marking their settlement in Israel have not allowed them adequate time to mourn their losses, accounting for the increasing rates of suicide and trauma-induced depressions.

In line with Indigenous people's healing practices and Freud's argument, a widow engages in a painful and laborious retrieval of the psychic energy invested in each memory and association with the deceased during the protracted bereavement rituals in the pre-colonial WeppaWanno community. The pain diminishes with the progress of the mourning and at the end, all energy are retrieved for investment in new relationships (in Kahn, 2002). Consequent upon his interest in the subject of grief reaction, a Boston psychoanalyst, Erich Linderman observed that to liberate oneself from the pain and paralysis of acute grief it is necessary that mourning process be completed. According to him, incomplete or absence of mourning will entrench the bereaved person in depression, interpersonal withdrawal, loss of interest in life and such physiological problems as ulcers (p. 177). Also critical to our understanding of the pre-colonial WeppaWanno widowhood experiences in the long process of ritualized recovery program is Kahn's (2002) observation that to liberate themselves, most bereaved people must allow themselves to cry, be willing to talk a good deal about the loss, the pain of the loss, and what they anticipate the loss will mean in their lives, express any guilt and anger they feel towards and for the lost person, and be given empathetic support for these (p. 180). The works of Parkes (1996); Gorer (1965) and Linderman (1944) stress the need for extensive mourning to liberate the bereaved from paralyzing grief and enable them go on with their lives.

\section{WeppaWanno People and Their Pre-Colonial Gendered Female}

It is pertinent for me to explain at the onset the binary female categories and statuses in pre-colonial WeppaWannoland in order to elucidate the cultural changes, and by extension changes in widowhood traditions prompted by the two foreign invasions of this indigenous community. The social position of every pre-colonial Weppa-Wanno female was assigned, based on customary positioning at birth. This practice also influenced how inheritance, title and power relations as well as forms of 
marriage were enacted and legitimized. In other words, the experience of widowhood rituals an indigenous WeppaWanno woman shared was a function of her natural position at birth (within the socially established binary category of Amoya and Adegbe). The first position, Amoya in Weppa-Wanno affects all the odd numbers among the female children of a family. Adegbe status is assigned all the even numbers of a family's daughters. In other words, every first, third, fifth, and so on, female child born in a family in Weppa-Wanno belong to the category Amoya while the second, fourth, sixth, and so on are Adegbe.

The positioning of Adegbe and her off-spring in a complex relationship of power and preeminence over Amoya, and often over their male brothers, could be a reinvention and repositioning of female authority that existed in the community's early migration history (Anaehomhe, 1980: p. 23; Nwalutu, 2004: p. 5). By virtue of her birth positioning Adegbe masks as, and performs "male" as a gender constructed by the society in which she lived. The Adegbe marriage is the union between a man and a woman obtained by the payment of a small dowry by the former. Male children of this union belong exclusively to the woman and her extended family, and the dowry or bride price paid on the daughters born from this union is divided equally between the husband's and the wife's families. This type of marriage contract entitles the man to the sexuality of his wife only. Leslie Ogundipe (2004: p. 75) succinctly argues that it is within marriage that Nigerian women suffer the most oppression. Her exemplar points to the loss of privilege and status by the female daughter or sister shortly after marriage. She reasons that with marriage, a daughter automatically transitions to being a client or possession. She becomes voiceless and often rightless in her husband's family. Ogundipe's narrative tacitly describes the experience of the post-colonial Nigerian female, and an Amoya daughter in the pre-colonial and even the earlier post-colonial WeppaWannoland. The reader would not just be puzzled to observe that contrary to Ogundipe's view, an Adegbe enjoyed more privileges than her male siblings both in her father's home as a daughter and in her husband's home after marriage, but be tempted to ask why this binary treatment exists for female daughters of same parentage. A comparable system is in place for sons as well. For example, only the Adegbe son is entitled to take the Okhe title in his father's life time (Ajawe, 2002; Ajegba, 2004). Only the Adegbe son can become an Obotsu (clan high priest) because titles can be made for them as soon as they are born and as such they can rise to the rank of a priest (Obotsu) and qualified to hold the Akwi staff specific to that office. Moreover, the oldest Adegbe in her father's kindred and village is entitled to hold a priestly title called Oseghie and occupy a position known as Ekwi or Okwekwi. This position elevates her from the rank of a senior elder to that of a semi-deity in her life time, and at death she joins the rank of village ancestors. In this position, each year which begins with the Ukpe (New Yam) festival in August, she is expected to carry her Ubechi (a woven tray), a table and chair to the market place where she takes her place alongside the male elders of the village. Women bring young children to her; she carries them and places them on her table, pronounces blessings on them and sets them down. In return the grateful mothers drop gifts on the tray (Emhoabino, 2003; Campbell, 2002; Charles, 2002; Campbell, 2001). All these socially ascribed benefits and the nexus of social responsibilities an Adegbe daughter was entrusted with also accounts for why
Adegbe widows in the pre-colonial WeppaWanno were not subject to familial or communal taboos and rituals. If she engaged in widowhood rituals after her spouse's death, unlike an Amoya, she undertook them voluntarily.

Judith Butler arguing that feminity is not a product of choice but the forcible citation of a norm, made a case for proliferation of gender beyond the binary frame of "man" and "woman", to encompass individual performance, so that other categories such as "Adegbe" might be a means to undermine heterosexual presumptions, rather than just a paradigm of gender performance (1993: p. 23f). Also Amoah (2007) called for the theorizing of different types of women whose "differences are marked by age, religion, class, sexual orientation, geographic location, and gender, all of which impact upon the experience (and reflection) of gender" (p. 98). However the Adegbe performative of maledaughter hasn't to do with her sexual orientation. She is physiologically strictly "female" but her society accorded her the transgender male position in her cultural space. Adegbe marries a person of the opposite sex (Ajakwe, 2002; Ajegba, 2004; Emhoabino, 2003; Campbell, 2002; Charles, 2002; Campbell, 2001). She may also live with or have external maleconcubines. However, in case of infertility in marriage she reserves the right to marry a wife for her husband who will serve as a second wife, and the aim is to secure offspring for herself and her husband, making procreation the main motivator. The Adegbe, in fact, performs almost all the exclusively male social duties, and enjoys the accompanying privileges. For example, an Adegbe is not only initiated into the exclusively male cults and masquerade groups, she also receives her share of village land and builds her house like her male brothers, because Adegbe is a male-daughter. Unlike her Amoya sisters and brothers, she is not bound by community taboos, and at marriage she could voluntarily perform widowhood rituals in case she lost her spouse. She remained under no obligation to perform widowhood rituals. The status of Amoya remains the same as ascribable to women in every other patriarchal society in Africa. She is a female daughter. The term Amoya also indicates an actual wife or "full" marriage resulting from the payment of a full dowry by a suitor to the family of a female spouse. After the rituals of marriage were enacted, she would be incorporated into her husband's family or household and her children would belong to his extended family (Amhofueshi, 2002; Akheonovao, 2002). At death an Amoya is expected to be buried in her husband's home and would not be entitled to a second burial. Amoya is bound by all the taboos of the lineage, village and the intra-communal taboos. Although all the WeppaWanno pre-colonial traditional rituals including the widowhood enactments were imperative for an Amoya wife, they were not mandatory for an Adegbe. However the Nupe (Islamic incursion of the late $18^{\text {th }}$ century), and the Western colonial annexation of the late nineteenth century (and by extension Christian missionary influence) not only eroded the existing binary opposites in WeppaWanno women's categories but extirpated most of the community's traditions, leaving in its trail, only an encapsulation of the people's cultural heritages and obvious psychological distress. Although the WeppaWanno widowhood ritual is extant - in its postcolonial state-it is a watered down and waning tradition.

\section{Widowhood Bereavement Rituals in the Pre-Colonial WeppaWannoland}

A review of the indigenous people's peculiar and extensive 
spiritual purification ritual which is designed to provide a three-dimensional (spirit, soul and body) healing to the bereaved person is the major motive of this investigation. I must stress at this juncture that as a justification for this investigation, the peculiarity of the WeppaWanno traditional practices stemmed from the impact of double cultural encounters that resulted in what Lori Colomeda and Eberhard Wenzel referred to as culture collision (2000: p. 251). Widowhood and bereavement is a tensed mourning and grieving period in the life of a female spouse who loses her husband (Aderinto, 2001; Fasoranti \& Aruna, 2007). All over the world, it is recognized that the loss of a loved one is a source of intense emotional stress (Kahn, 2002), and given the prevailing customs and traditions, the bereaved express and deal with their feelings of loss in order to regain their lives.

The pre-colonial widowhood bereavement ritual in WeppaWannoland has three stages which are equally important as they are meant to address the three dimensions of humanity: the soul, spirit and body (Emhoabino, 2003; Campbell, 2002; Charles, 2002; Campbell, 2001). The first phase (soul tiebreaking) starts at the point of death of a woman's husband. The widow is separated from the remains of her husband and she is allowed to wail and mourn as freely and extensively as she would as she proceeds to her natal home to inform them of the death that has visited her. She is accompanied on a wailing trail through major villages of WeppaWanno to her natal home by a group of consisting of all married women in her marital village (Ajakwe, 2002; Ajegba, 2004; also see Mbiti, 1975). The Ikpoba and Ukpogho (female and male elder in her marital village quickly converge to wail after the widow's train leaves). The women's group of her natal village on hearing the wailing train would join it to return her to her husband's house before the funeral begins. As soon as the wailing-train returns the widow and her children are ushered into a mourning chamber and the funeral commences (Ighietsemhe, 2002; Inakhe, 2002, Achebe, 2005). The widow, and to a lesser extent her children, are excluded from all communal work. She is also not allowed to engage in any familial chore for a period of time from seven days to three months from the day her husband is laid to rest. It is important to mention here that this process applies to male and female alike, although it depends on the peculiarity of situation. All familial functions like cooking, fetching water and firewood are undertaken by volunteers from both the women's groups and the Otu or age grades to which the couple's children belonged (Anaemhomhe, 1980; Nwalutu, 2004, Achebe, 2005), to allow the woman and her children sufficient time for soul searching and recovery. At her husband's burial, the widow is provided with a piece of white cloth that has to be torn according to the number of children she had with her spouse. When the coffin is lowered into the grave, it is opened for the last time and the widow and her children each present a piece of the cloth to the deceased, informing 'him' that that is the cloth his child (name mentioned in each case) uses to send him on his way (Ajawe, 2002; Ajegba, 2004). Finally the widow uses the wrapper that she wore during her husband's sickness and death to perform the same ritual.

The second phase has a longer duration, lasting up to three months from the day the husband is laid to rest. The widow wears mourning dress made of black cloth for three months (in some villages, white was preferred). This was a crucial period of spiritual enactments accompanied by customary rituals of purification and sacrifices as prescribed by the village di- viner(s). It culminates in the deceased person's second funeral if he so deserved. At the end of the three months of mourning, the widow would go to the farm road with a small knife in her hand, and weep for her husband all over again. It is important to note at this juncture that the rite of severance of the marital union between a deceased man or woman as a continuous ritual goes on through one year of mourning (Anaemhomhe, 1980; Isichei, 1983; Fasoranti \& Aruna, 2007). The final ritual occurs one full indigenous calendar year after the death of the widow's spouse. The two most important enactments for the widow were the "the mourning clothes removal ritual" that took place at the Unuchi shrine in the widow's marital home (an extended family shrine under the supervision of an Obotsu or Omo Unuchi in whose compound the shrine was located). Through this enactment the relationship between her and her late husband was severed and she was then free to remarry her late husband's brother or a man from any other homestead in the community (Anaemhomhe, 1980; Okeke-Ihejirika, 2004; Opara, 2000).The second event was the ceremonial "cleansing bath" which took place at night at the Oghor River, officiated by the Owa Ikhute priest or priestess (The chief priest of WeppaWannoland) and the oldest Adegbe women from the widow's marital and natal villages. Other rituals and sacrifices were conducted to ensure that the widow's new husband would not die of spiritual affliction in the event that any of the rituals was left out. I wish to further expatiate on the mourning clothes removal ritual at this point. At the end of the grieving period for an Amoya or Adegbe widow (all rituals and taboos are voluntary for Adegbe but imperative for Amoya), she changes her wrapper. Before she does this, she consults the diviner. What the oracle prescribes for her to provide is what she takes to the Unuchi (shrine) of her husband's family. It is believed that the spirit of her late husband communicates with her through the oracle, and the demand of the oracle is assumed to be her late husband's demands. The items requested by the oracle are considered to be what her late husband needs in order to free her from their relationship. The prescribed items usually include a he-goat or rooster (as directed), some quantity of red oil and palm kernel oil. At the end of the mourning period, the woman buys a piece of white cloth to be tied on her by an older Adegbe. A few days later, the he-goat or rooster she purchased is taken to the Unuchi (shrine) along with the white cloth she now removes. At the Unuchi, the Omo Unuchi slaughters the animal and sprinkles its blood on the white cloth called "ataza" which he ties on the Unuchi shrine. "Ataza" means the removing of mourning cloth and signifies that the widow is now free to leave her husband's family and/or marry any man of her choice. Her husband's family retains no more claims to her. An Amoya who loses a husband and is not willing to remain in her husband's family is also expected to perform this ceremony. However, only the Adegbe may change her mourning wrapper and wear another dress during her widowhood. An Amoya must wear black clothes throughout this period. The ritual will also be performed at the widow's late husband's Unuchi. In Wanno, the most senior Amoya wife performs this ritual for an Amoya whose husband dies and the cloth is returned to her husband's Unuchi. In Weppa an Adegbe performs this ceremony for an Amoya whose husband has died.

It is believed that if an Amoya widow fails to carry out this ritual and a member of her late husband's family marries her, the consequence would be death for the new husband. The new suitor is expected to bring 1 shilling 9 pence (the equivalence in 
Naira today) to the Omo Unuchi which is the cost of purchasing the white cloth for Ataza that the widow removed. The custom also requires this widow to sleep with another man who is not a member of the widow's husband family before her new husband brings her to his house in order to ward off a certain death that befalls a potential husband if this is not done. This ritual was incumbent on an Amoya widow who wished to remarry, but was not binding for an Adegbe widow. She was free from such taboos.

\section{Changing the Cultural Trajectories: Nupe Invasion and British Colonization Project in WeppaWanno}

Areas along the Niger-Benue river, and particularly the area of the two rivers' confluence, witnessed in the $19^{\text {th }}$ century a struggle for supremacy over the monopoly of trade with British merchant companies. For any group to win, they had to have access to weapons of warfare, men of war and also be in the position to produce the desired commodities for exchange. It was the commercial interests of the British merchant capital that provoked Bida slave raids into Weppa-Wannoland, south of the confluence and adjacent to the Niger river. To King Masaba of Nupe, the advantages of trade with the Europeans were obvious, and a year after captain McCoskry, (a British merchant sailor)'s visit, Masaba was demanding muskets and gun powder from Baikie. The year after Baikie's departure in 1865, regular exchange with European trade ships began on the Niger. In reference to the volume of trade goods in that same year, 1865, Whitford who had thought he would fill an European ship annually with ivory, palm oil, shea butter, lead ore (galena) and cotton was surprised that the response he got to trade was beyond his imagination. He later wrote "we anchored off Eggan (near the present day Lokoja)... and in 3 weeks bought 5 T. of ivory, $6 \mathrm{~T}$ or $7 \mathrm{~T}$ of shea butter and several thousand country cloths; latter for sale on the coast”( Mason, 1981; Nwalutu, 2004; Oshomha, 1993). Contradictions exist in the various sources as to the factors that motivated the Nupe invasion of WeppaWanno. Haruna (2003: p. 412) corroborated the accounts of Anaemhomhe (1980) and Nwalutu (2004) both of which insist that economic conquest and slave trade were the motivateing factors in the Nupe invasion of WeppaWanno. As with every other imperialist conquest, this was soon followed by religious cum cultural domination.

The account of Bello-Imam (1995) takes a different trajectory. In his words, "Nupe invasion which is a derivative from the Jihad of Uthman Ibn Fudi of the $19^{\text {th }}$ century is the antecedent and indeed precursor of the islamization of South Ibie people” (p. 97). The development of slavery in Hausaland was only remotely connected to the demands of the world market. Every three years, Bida (Nupe) raiding forces moved into Weppa-Wanno, usually in the dry season, and these invasions occurred consistently from about 1857-1895 when they were finally rebuffed by Weppa-Wanno local forces. The invading army consisted of both males and females (disguised as males) mounted on horseback and armed with guns, swords and spears (Ajakwe, 2002; Ajegba, 2004). The villagers were ordered to submit a specific number of persons or face a military action. If a village proved recalcitrant, villagers were harassed and in the ensuing confusion, some individuals were tracked down and taken captive. From 1861 onwards, Etsu Masaba's army became fiercer and more ruthless in their approach, burning villages and looting their food stores, resulting in famine and epi- demics. The Nupe were not without the co-operation of local volunteers and accomplices. In Weppa-Wanno, such agents or slave dealers as Ikhegbe and his son Obozuwa in Iviukhua, Etsukha of Iviegbepui, Ogai of Iviebua and Asekhamhe of Imiava emerged (Ajakwe, 2002; Ajegba, 2004; Emhoabino, 2003; Charles, 2002). They took the initiative to acquire slaves for exchange with the Nupe slave raiders. These partners also worked together in the procurement and final disposal of captives.

\section{Resistance to Nupe-Raids and the Loss of Adegbe as a Social Power Construct}

In about 1862, the Ukpi Drummers (top title holders) across WeppaWanno communities decided to confront the problem of incessant slave raids by Islamized Nupe forces, and possibly solve it through negotiations with the Nupe generals. These negotiations resulted in the leadership being forced into signing a treaty accepting Nupe dominance. Not only were they required to send an annual tribute of harvested crops to the King, Etsu Masaba, but they were also told that they must send human tribute once every three years to Bida, or face continued slave raids. Some Ukpi drummers who complied became Islamic converts. To meet the other requirements of the treaty, orphans and children of the very poor were sent as slave tributes to the Nupe Kingdom by the powerful WeppaWanno warriors who, by excelling in strength through military escapades, began to collaborate with the invaders (Bello-Imam, 1995; Harunah, 2003; Ajegba, 2004; Emhoabino, 2003). The WeppaWanno warriors who become slave supplying agents to Nupe kingdom were Ikhegbe and his son, Obozuwa in Iviukhua; Etsukha of Iviegbepui, Ogai of Iviebua and Asekhambe of Imiava. "They took the initiative to acquire slaves for exchange with the Nupe slave raiders. Theses partners also worked together in the procurement and final disposal of captives" (Nwalutu, 2004: p. 47). Those who refused to comply, fled, deserting their towns and villages.

One obvious consequence of Nupe raids in Weppa-Wanno was the creation of a new set of social relations, patron-client relationships replacing relatively egalitarian structure that predated the invasion. The mighty and powerful dominated the weak and poor. Kinship idiom broke down almost completely to make room for patron-client relationship in which the weak and poor depended on the powerful for protection and to some extent, economic survival in return for services rendered in form of agricultural labor. For the weak to continue living he had to attach himself or come into the protection of a powerful man by building his house right beside his and making his fence to touch his patron's wall (Ajakwe, 2002; Ajegba, 2004; Emhoabino, 2003; Nwalutu, 2004). This also meant that the powers enjoyed by less noble men in WeppaWanno society (who were either weak or unable to procure arms); and by extension the Adegbe female, melted away into the protective embraces of the rich and powerful WeppaWanno warriors. By so doing the poor came under the protection of the rich and under his service. He automatically became unwilling slave to his patron. It was under this type of uncertain socio-political and economic atmosphere that the British chartered companythe Royal Niger Company followed closely by the British colonial machinery and missionary groups made their way into WeppaWanno land in 1897. It is worth the emphasis here to 
hint that the strategies of evangelization used by the Christian missionary outreaches were far more appealing to the people of WeppaWanno than the forceful islamization they faced under the Nupe raids earlier in the century. Besides, their inability to align Christian missionary activities with the disruptions and chaos perpetuated on their socio-cultural life by the Western colonial project made people's positive disposition to Christian faith inevitable. Many therefore became converted from traditional and Islamic religions to Christianity.

\section{The Royal Niger Company (RNC) and the British Penetration of WeppaWannoland}

The history of the Royal Niger Company is a history of mergers, outbidding, and buying out weak firms. In 1875, a liquidated Holland Jacques and company were bought by John Sendhouse Goldie Taubman, and his younger brother, George Goldie Taubman was put in charge. Out of this company, the Central African Company was formed in 1876. In 1879, the United African Company was formed as an amalgamation of the West African Company, Miller Brothers, James Pinnock and the Central African Trading Company to check the threat of the French firm Compaigne Francaise del'Afrique Equatoriale. In 1882 in order to expand its assets, a new company, the National African Company was floated which took the assets of the United African Company. It was the National African Company that obtained the charter on the $10^{\text {th }}$ July 1886 and changed its name to the Royal Niger Company Chartered and limited (Isichei, 1983; Bradbury, 1973; Bradbury, 1957). The title for its chairman and Vice-chairman became Governor and Deputy Governor respectively, thus started the colonization of the various nations that later formed Nigeria.

Historical sociologists have referred to this imperialist aggressive conquest and occupation of colonies as systemic cycles of capitalist accumulation. The British era which ended in the 1920s culminated in the period of financial expansion that also saw the uprising of an American cycle. The historicization of Weppa-Wanno imperialist experiences continue to point to two major external dominating incursions that influenced its contemporary socio-cultural life. But many social and cultural analysts deliberately or unwittingly prefer to address only Western colonization, leaving out the earlier Islamic disruptions, which definitely leaves a gap in the historicizing of WeppaWannoland. The Royal Niger Company by 1896 began its penetration of the Weppa-Wanno towns and had as its priority the 'total abolition of slavery' and all forms of enslavement in order to free labor from servitude. Although a laudable goal, and one no doubt taken seriously by Christian missionaries, it supported the company's goal of "buying cheap and selling dear". The company had realized that if it must make profit, it would be easier for her to negotiate cheaper prices from small scale independent but numerous producers of palm oil, palm kernel and cotton than with few large client holders.

The devolution of leadership roles to male-only aristocrats following the Nupe invasion placed four major holders of Ukpi chieftaincy drums along with the Owa Ikhuthe shrine priest into WeppaWanno in positions of leadership. This team also constituted the jury of final appeal in all WeppaWanno disputes, representing a complete shift from the supreme council of three female judges that had obtained in the society's early migration period between $12^{\text {th }}$ and $15^{\text {th }}$ century A.D. (Anaemhomhe, 1980; Nwalutu, 2004). Thus both male and female indigenous peoples were simultaneously victims of Islamic and British subjugation and control throughout the region originally referred to as the Oil River Protectorate (of which WeppaWanno was a part) prior to the amalgamation of Nigerian sub-regions into a country in 1914 (Isichei, 1983; Achebe, 2005; Amadiume, 1997; and Mba, 1982). Both genders were, in their various capacities, involved in the resistance and struggles for independence, albeit the efforts by the male pressure groups, activists and nationalist were given more media attention.

\section{WeppaWannoland under Company Rule}

The British defeat of the Bida emirate in 1897 and the liberation of slaves and captives henceforward, led to a tremendous increase of the Royal Niger Company's operations, leading to the "opening up" of the hinterland and the search for new economic opportunities for British merchant capital. This eventually culminated in the opening of trading posts in Egori waterside (in the present day Agenebode waterfront) by the Royal Niger Company. The Royal charter awarded to the Royal Niger Company empowered it to exercise "all rights, interests, authorities and powers for the purpose of governance (and the) preservation of public order". The implication of this is that the Royal Niger Company could maintain their own police force, a constabulary or military force, set up courts (which over-ran the existing customary court), and impose taxation. The company employed some WeppaWanno sons in the police force. In WeppaWanno the mobile court heard cases in the Royal Niger Company's premises at Egori waterside. I have to interject here that it was at this point that modernity and tradition collided. The British interest in the Niger area was purely economical and borne on the wings of the machinery of capitalist accumulation. The debunking of African concept of indigenous African communal and selfless leadership pattern gave way to individualism and competition as is evident in every quarter in Western civilization today (Ngunjiri, 2010: p. 169). Female power and societal roles in WeppaWanno as in other colonized African nations became marginalized and repudiated (Okafo, 2009; Haruna, 2003; Nwalutu, 2004; Anaemhomhe, 1980). In the traditional WeppaWanno society, as is the case in other African societies, the notion of leadership as solely the business of men was alien because to Africans gender roles are harmonizedmeaning that while gender roles were complementary-leadership roles tended to be in the hands of men or older women beyond the age of menopause.

Philomina Okeke-Ihejirika regrets the limitations that emerging Westernization placed on the mobility of traditional African women, and by extension men, who now have their social relationship "structured within a hybridized social order where men and women must deal with both foreign and indigenous dictates that were brought together through Western influence" (OkekeIhejirika, 2004: p. 4). Thus Adegbe females had to negotiate their place within a new social order, as subordinates of their male counterparts. Evident in Eboh (2000) and Ogundipe (1994) is the fact that foreign incursion into African societies eroded many of the traditional cultural and socioeconomic opportunities African women had-opportunities that were neither recent nor post-colonial. This displacement is one of the bases for the contemporary Amoya and Adegbe (and by extension, these women as widows) struggle to regain their culturally assigned positions, with their rights to good health and privileges in WeppaWanno society. 


\section{Implications of Foreign Domination and Cultural Encapsulation for Traditional Widowhood Rites in WeppaWanno}

I will continue by arguing that the post-independent WeppaWanno patriarchal society, like every other community in western Nigeria, has evolved not from its cultural past but from a past incorporating the double cultural tragedies implicated in the Nupe Islamic invasion and British colonial rule (Haruna, 2003; Nwalutu, 2004; Anaemhomhe, 1980; Opara, 2000; Okeke-Ihejirika, 2004). The regents of the Nupe kingdom and subsequently the British ruling authorities replaced "subjugated knowledge with their own specialized thought because they realized that gaining control over this dimension of subordinate groups' lives simplified control” (Collins, 1990: p. 226). The traditional extended family structures that were mutually communal gradually gave way to Western and Islamic style nuclear family structures that were more individualistic and egocentric (Okafo, 2009: p. 101; Haruna, 2003: p. 494; Nwalutu, 2004: p. 54; Anaemhomhe, 1980: p. 55). The incompatible cultural blend introduced by both Islamic and Christian incursions in WeppaWannoland brought about significant changes in widowhood bereavement traditions, with consequent retrogressive outcomes on the indigenous people's social, mental, spiritual, and physical health.

In the resulting dilemma that plays out in WeppaWannolandAdegbe daughters and widows in the community are unable to access justice from the extinct traditional justice system that established them-now replaced with English and Sharia customary court that bears no relevance to the community it was meant for and in which they place no confidence. Also claims of Adegbe widows' male offspring to the leadership positions have been successfully challenged and thrown out of the British court system inherent in contemporary WeppaWanno jurisprudence. Many Adegbe daughters and their children have been ruled against in the recent past because the substance of these cases found no validation in post-independence British patriarchal codes (Okafo, 2009: p. 111; Kukuru Division 130 K.D. 2, National Archives Ibadan). As more and more indigenous family structures have been redefined through women marrying in either the Eurocentric (Christian), or Arabic (Islamic) forms of marriage, Adegbe status gradually has become a titular position, devoid of power and fame. Consequently both Amoya and Adegbe widows now have to abide by the dictates of a culturally hybrid form of widowhood containing few, if any, indigenous values. In the light of this development, the widowhood practices that were originally designed for healing and psyche recovery of the bereaved have been downplayed as superstitious ritual. They are now observed as merely social ceremony with little or no attached spiritual values. The widow-converts to Islam have only a few days of mourning permitted by the Quran. Christian converts limit their funeral and mourning to between seven and thirty days from the day a spouse dies. In fact, some Christian denominations in WeppaWanno require funeral services to be carried out within seven days, and no special ritual observation is permitted thereafter. Anthropologists and psychologist frown at Western bereavement practices that they collectively consider inadequate and untoward. Gorer and Burgoine (1965) particularly regret that northern Europe and North America considered "more than a little mourning unseemly". Parkes (1996), who attributed this weakness to the inability of Europe and North America to ritualize mourning and provide religious and institutional opportunities for it, believes that the bereaved in Western societies fare significantly worse than those in traditional societies.

\section{Conclusion}

In this exercise I examined documented evidence of, and literature on, widowhood rituals that existed before the Nupe (Islamic) invasions and Western (Christian) colonization of WeppaWannoland in order, first, to problematize the brief and uneventful Islamic and Christian widowhood bereavement practices that perpetuate post-bereavement depression and related mental abnormalities. Second, this work has succeeded in highlighting the critical role of indigenous bereavement rituals on the health and recovery of widows. Third, I have succeeded in engineering a thought process that will continue to interrogate the legacy of colonial domination over cultural practices. Finally this exercise contributes to the growing literature on the rituals of indigenous widowhood bereavement as part of a healing process, with the hope of reviving interest in this gradually disappearing tradition, and generating scholarly debate to stimulate its recovery. Moreover, contemporary African legal systems are fraught with overt and covert sexist interprettations of customary law incorporated by the African male authorities that served the colonial regimes (Okeke-Ihejirika, 2004). Such sexist interpretations tend to strengthen men's privileged positions while women are left at the margin to contend for their property and marital rights, often on very uncertain grounds (p. 6). Dismantling the machinery of colonialism inherent in post-colonial African societies (and in those of other indigenous peoples all over the world) has become the priority of African decolonizing projects in both social and academic spheres. I will draw from Mudimbe’s injunctions to “decolonize the social and human sciences by destroying the myths of 'Africanity' and mystifications inherited from the 'inventors' of Africa and her culture (1988: p. 37)”. I strongly believe that reinvention of such traditions of indigenous people as widowhood rituals will benefit the people of WeppaWannoland for they have much to offer in aiding recovery from loss-induced trauma. This case study affirms the need for indigenous sociologists and scholars to prioritize rediscovering traditional health and healing practices that have been castigated, debunked and overlooked by mainstream sociologists.

\section{Acknowledgements}

This paper is an attempt to publish the report of a rigorous field research funded by Mr. Joseph Aken'ova from 2001-2004 in honor of his late father Pa Michael Isibor Aken'ova and in appreciation to his mother, late Madam Lucy Aken'ova for their exemplary parenting.

\section{REFERENCES}

Achebe, N. (2005). Farmers, traders, warriors, and kings: Female power and authority in Northern Igboland, 1900-1960, Social History of Africa. Portsmouth, NH: Heinemann.

Aderinto, A. (2001). Subordinated by culture: Constraints of women in rural Yoruba community, Nigeria. Nordic Journal of African Studies, 10, 176-187.

Amadiume, I. (1997). Reinventing Africa: Matriarchy, religion \& culture. New York: Zed Books Ltd.

Amoah, J. (2007). Building sandcastles in the snow: Meanings and 
misconceptions of the development of Black feminist theory in Canada. In N. Massaquoi, \& N. Wane (Eds.), Theorizing empowerment: Canadian perspectives on Black feminist thought. Toronto: INANNA Publications and Education Inc.

Anaehomhe, A. (1980). The history of WeppaWanno. Auchi: Toba Printers.

Arrighi, G. (1994). The long twentieth century: Money, power and the origins of our times. New York: Verso

Arnfred, S. (Ed.) (2005). Re-thinking sexualities in Africa. Uppsala: Nordic African Institute.

Balick, M. (2006). Ethnomedicine: Ancient wisdom and modern science. Explore, 2, 239-248.

Bell, R. (2002). Understanding African philosophy: A cross-cultural approach to classical and contemporary issues. New York: Routledge.

Belsey, C. (2002) Poststructuralism: A very short Introduction. New York: Oxford University Press.

Bello-Imam, I. (1995). An ethnographic survey of south Ibie clan of Etsako West local government of Edo State, Nigeria. Ibadan: Vantage Publishers.

Berger, I., \& White, F. (1999). Women in Sub-Saharan Africa: Restoring women to history. Bloomington and Indianapolis: Indiana University Press.

Bradbury, E. (Ed.) (1973). Benin studies. Oxford, London: International African Institute, University Press.

Bradbury, R.(1957). The Benin Kingdom and the Edo-Speaking Peoples of South-Western Nigeria, with a section on the Itsekiri by P. C. Iloyd. Ethnographic Survery of Africa, Western Africa. London: International African Institute.

Brown, W. (1993). Wounded attachments. Political Theory, 21, 390410. doi:10.1177/0090591793021003003

Burk, C., \& Speed, B. (Eds.) (1995). Gender power and relationships. London: Routledge.

Butler, J. (1992). Contingent foundations: Feminism and the question of "postmodernism". In J. Butler, \& J. Scott (Eds.), Feminists theorize the political (pp. 3-21). New York: Routledge.

Butler, J. (1997). Excitable speech: A politics of the performative. New York: Routledge.

Butler, J. (1990). Gender trouble: Feminism and the subversion of identity. New York: Routledge.

Colomeda, L. (1999). Keepers of central fire: Issues in ecology for Indigenous People. Mississuaga: Jones and Barlet Publishers.

Colomeda, L., \& Wenzel, E. (2000). Medicine keepers. Issues in Indigenous health. Critical Public Health, 10, 243-256. doi:10.1080/713658247

Collins, P. (1990). Black feminist thought in the matrix of domination. In P. H. Collins (Ed.), Black feminist thought: Knowledge, consciousness, and politics of empowerment. Boston: Unwin Hyman.

Cornwall, A. (Ed.) (2005). Readings in gender in Africa. London: International African Institute.

Davies, B. (2006). Subjectification: The relevance of butler's analysis for education. British Journal of Sociology of Education, 27, 425438. doi:10.1080/01425690600802907

Dompere, K. (2006). Polyrhythmicity foundations of African philosophy. London: Adonis \& Abbey Publishers Ltd.

Errington, S. (1995). Recasting sex, gender and power: A theoretical and regional overview. In J, Atkinson, \& S. Errington (Eds.), Power \& difference: Gender in island Southeast Asia, Stanford: Sanford University Press.

Eze, E. (Ed.) (1998) African philosophy: An anthology. Malden, MA: Blackwell Publishers Inc.

Fasoranti, O., \& Aruna, J. (2007). A cross-cultural comparison of practices relating to widowhood and widow-inheritance among the Igbo and Yoruba in Nigeria. Journal of World Anthropology, Occasional Papers, 3, 53.

Foucault, M. (1982). The subject and power. Critical Inquiry, 8, 777-795. doi:10.1086/448181

Harunah, H. (2003). A cultural history of the Uneme: From the earliest times to 1962. Lagos: The Book Company Limited.

Herbert, E. (1993). Iron, gender and power: Rituals of transformation in African Societies, Bloomington and Indianapolis: Indiana University Press.

Ikuenobe, P. (2006). Philosophical perspectives on communalism and morality in African traditions. Oxford: Lexington Books.

Isichei, E. (1983). A history of Nigeria. Essex: Longman Group Limited.

Johnston, S. (2002). Native American traditional and alternative medicine. The ANNALS of the American Academy of Political and Social Science, 583, 195-213. doi:10.1177/0002716202583001013

Kapur, R. (2005). Erotic justice: Law and the new politics of post-colonialism. London: Glass House Press.

Linklater, R. (2010). Decolonizing our spirits: Cultural knowledge and indigenous healing. In S. Marcos (Ed.), Women and Indigenous religions, Santa Barbara: Praeger.

London, George Allen \& Unwin Ltd., \& Fanon, F. (1991). History of education in Nigeria. Medicine and colonialism. In a dying colonialism. New York: Grove Press.

Mason M. (1981). The foundations of the Bida Kingdom. Zaria: Ahmadu Bello University Press.

Mba, N. (1982). Nigerian women mobilized: Women's political activity in Southern Nigeria, 1900-1965. Berkeley: University of California, Institute of International Studies.

Mudimbe, V. (1988). The invention of Africa: Gnosis, philosophy, and the order of knowledge. Indianapolis: Indiana University Press.

Newell, S. (1995). Images of African women: The gender problematic. Occasional paper number 3. Stirling: Center of Commonwealth, Studies University of Stirling.

Ngunjiri, F. (2010). Women's spiritual leadership in Africa: Tempered radicals and critical servant leaders. Albany: State University of New York Press.

Nwalutu, F. (2004). Weppa-Wannoland in historical perspective, Etsako East local government area, Edo-North, Nigeria. Benin City: Nigeria, God's Heritage Communications.

Okafo, N. (2009) Reconstructing law and justice in a postcolony. Interdisciplinary research series in ethic, gender and class relations. Burlington: Ashgate Publishing Company.

Ogundipe-Leslie, M. (1994). Re-creating ourselves Africa women \& critical transformations. Lawrenceville, NJ: African World Press Inc.

Opara (2000). The concept of otherness in African feminist thought. In M. Eboh (Ed.), Philosophical criticisms: Anthropology of gender issues. Port Harcourt: Pearl Publishers.

Okeke-Ihekirika, P. (2004). Negotiating power and privilege: Igbo career women in contemporary Nigeria. Lancaster, OH: Center for International Studies, Ohio University.

Oshomha, I. (1993). The Edo and their neighbors of M. Western Nigeria. Ibadan: New Era Publishers.

Paterson, K., \& Hughes, B. (1999). Disability studies and phenomenology: The carnal politics of everyday life. Disability and Society, 14, 597-610. doi:10.1080/09687599925966

Pesek, T., Helton, L., \& Nair, M. (2006). Healing across cultures: Learning from traditions. Ecohealth, 3, 114-118. doi:10.1007/s10393-006-0022-z

Rasmussen, S. (2007). Introduction to Health knowledge and belief systems in Africa. In T. Falola, \& M. Heaton (Eds.), Health knowledge and belief systems in Africa. Durham: Carolina Academic Publishing.

Rosenberg, S. (2004). An introduction to feminist poststructural theorizing. In N. Mandell (Ed.), Feminist issues: Race, class and sexuality (4th ed., pp. 35-57). Toronto: Pearson/Prentice Hall.

Salih, S., \& Butler, J. (Eds.) (2004). The Judith Butler reader. Oxford: Blackwell Publishing.

Timothy, R. (2007). Third world women, women of color, and Minority women: An African/Black feminist analysis of our identities. In N. Massaquoi, \& N. Wane (Eds.), Theorizing empowerment: Canadian perspectives on Black feminist thought. Toronto: INANNA Publications and Education Inc.

Turner, L. (2006). The presence of spirits in healing. In Among the Healers: Stories of spiritual and ritual healing around the world. Westport Connecticut: Praeger Publishers. 


\section{Archival Documents}

1) H. C. B. Denton; Intelligence Report on Etsako Clans of Kukuruku Division. $25^{\text {th }}$ July 1936, Ministry of Local Government and Chieftancy Affairs, Benin City

2) Kukuru Division 130 K. D. 2, National Archives Ibadan

3) K. D. 578 Kukuruku Div 2. National Archives Ibadan

4) K. D. 765 Kuku Div 2. National Archives Ibadan

5) K. D. 174 Kuku Div 2. National Archives Ibadan

6) Kuku Div 83 Vol III, National Archives Ibadan

7) Edo State of Nigeria Gazette No. 8 Benin City $-22^{\text {nd }}$ February, 2001, Vol II Sect. B5 and B6.

\section{Interview Conducted by Felicia Nwalutu Ph.D; Michael Nwalutu, Martins Otseme and} Cletus Izoboh 2001-2004

\begin{tabular}{|c|c|c|}
\hline Respondents & Place of Interview & Date \\
\hline 1. Ajawe, Momoh (Chief) & Owah-Ovao & May 19, 2002 \\
\hline 2. Ajawe, Momoh (Chief) & Owah-Ovao & Aug. 18, 2002 \\
\hline 3. Ajawe, Momoh (Chief) & Owah-Ovao & June 14, 2002 \\
\hline 4. Ajawe, Momoh (Chief) & Owah-Ovao & Aug. 28, 2002 \\
\hline 5. Ajegba, Peter W. & Aviodo-Ovao & June 14, 2004 \\
\hline 6. Akheonovao, Idemosi & Agenegbode & Aug. 28, 2002 \\
\hline 7. Akheonovao, Idemosi & Agenegbode & May 18, 2002 \\
\hline 8. Akosi Yusuf & Agenegbode & July 2, 2002 \\
\hline 9. Amhofueshi Igebina (Pa) & Aghiere & Aug. 28, 2002 \\
\hline 10. Campbell Catherine (Madam) & Auchi & June 11, 2002 \\
\hline 11. Campbell Catherine (Madam) & Auchi & Nov. 2, 2001 \\
\hline 12. Charles John & Owah-Ovao & Aug. 18, 2002 \\
\hline 13. Echi, Mary Ebodethiomhe & Agenegbode & Aug. 28, 2002 \\
\hline 14. Eghabor, George Oshiapi Okumagbe of Weppa-Wanno) & Emokhemhe & Sept. 72002 \\
\hline 15. Ekhanaede Alexander Igenegba Babatunde Jimoh & Agenegbode & July 2, 2002 \\
\hline 16. Emhoabino, Vincent & Uyo & June 27, 2003 \\
\hline 17. Emokhor, Kadiri & Owah-Ovao & Aug. 18, 2002 \\
\hline 18. Enakhena, Joseph Steven (Pa) & Benin City & Nov. 7, 2001 \\
\hline 19. Igbodekhe, Momodu & Ivioghe & Aug. 28, 2002 \\
\hline 20. Igbodekhe, Mulemu Momodu & Ivioghe & Aug. 28, 2002 \\
\hline 21. Ighietsemhe, Ikhimebemhe & Iviukwe & June 14, 2002 \\
\hline 22. Ighietsemhe, Ikhimebemhe & Iviukwe & Aug. 28, 2002 \\
\hline 23. Inakhe, Patrick & Aviodo-Ovao & Nov. 4, 2002 \\
\hline 24. Group Interview with some Members of Isimekha quarters & Ivioghe & July 2, 2002 \\
\hline 25. Group Interview with some Members of Iviagbokwi family & Iviukwe & May 18, 2002 \\
\hline 26. Itseole Esimhokha (Pa) & Oshiolo & Aug. 28, 2002 \\
\hline 27. Itseole Esimhokha (Pa) & Oshiolo & Nov. 4, 2002 \\
\hline 28. Group Interview with some Members of Iviagbokwi kindred & Iviukwe & May 18, 2002 \\
\hline 29. Izoboh, Agiaye & Oshiolo & Nov 4, 2002 \\
\hline 30. Ogbake J. A. (Prince) & Aviodo-Ovao & May 20, 2002 \\
\hline 31. Ogbake J. A. (Prince) & Aviodo-Ovao & June 14, 2002 \\
\hline
\end{tabular}




\section{Continued}

\begin{tabular}{lcc}
\hline 32. Ogbechia Ogbolu & Aviodo-Ovao & Nov. 14, 2002 \\
33. Okaku family members & Aghiere & Aug. 17, 2002 \\
34. Okaku, Inomayo Itega, and Oshiomoba Aliu & Aghiere & Aug. 17, 2002 \\
35. Okpo Ighietsemhe Ikhunebemhe & Iviukwe & Aug. 28, 2002 \\
36. Okpo Ighietsemhe (Madam) & Iviukwe & Aug. 28, 2002 \\
37. Okumagbe \& His Council Chiefs & Agenegbode & Jan. 5, 2004 \\
38. Omoba Fati (Mrs.) & Ivioghe & July 2, 2002 \\
39. Omonia Sule & Owah-Ovao & Aug. 18, 2002 \\
40. Oshiomegie Matthew & Benin City & Sept. 27, 2004 \\
41. Ovoema, Matthew Ebakhalumhe & Agenegbode & Aug. 28, 2002 \\
42. Unuabode & Agenegbode & June 14, 2002 \\
\hline
\end{tabular}

